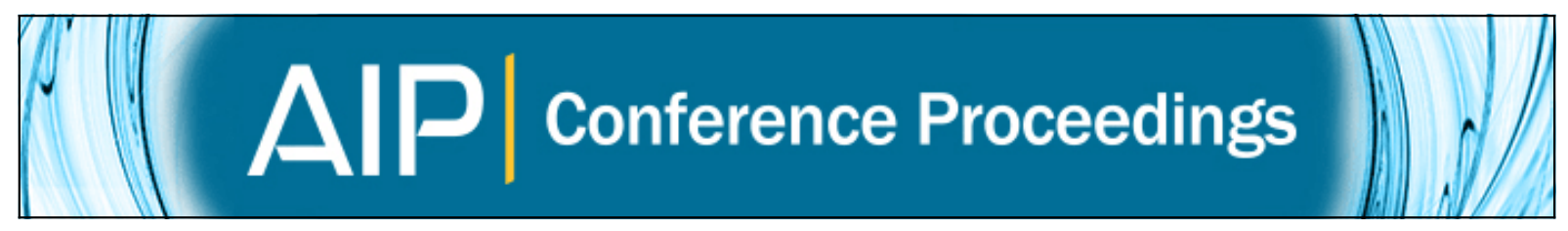

\title{
Hygroscopicity of nucleated nanoparticles in CLOUD 7 experiments
}

Jaeseok Kim, Helmi Keskinen, Petri Vaattovaara, Pasi Miettinen, Jorma Joutsensaari, Annele Virtanen, and CLOUD Collaboration

Citation: AIP Conference Proceedings 1527, 306 (2013); doi: 10.1063/1.4803264

View online: http://dx.doi.org/10.1063/1.4803264

View Table of Contents: http://scitation.aip.org/content/aip/proceeding/aipcp/1527?ver=pdfcov

Published by the AIP Publishing

\section{Articles you may be interested in}

Multi-species nucleation rates in CLOUD

AIP Conf. Proc. 1527, 326 (2013); 10.1063/1.4803269

Molecular steps of neutral sulfuric acid and dimethylamine nucleation in CLOUD

AIP Conf. Proc. 1527, 302 (2013); 10.1063/1.4803263

Measuring composition and growth of ion clusters of sulfuric acid, ammonia, amines and oxidized organics as first steps of nucleation in the CLOUD experiment

AIP Conf. Proc. 1527, 298 (2013); 10.1063/1.4803262

Particle nucleation events at the high Alpine station Jungfraujoch

AIP Conf. Proc. 1527, 222 (2013); 10.1063/1.4803244

Modelling new particle formation from Jülich plant atmosphere chamber and CERN CLOUD chamber measurements

AIP Conf. Proc. 1527, 173 (2013); 10.1063/1.4803231 


\title{
Hygroscopicity of Nucleated Nanoparticles in CLOUD 7 Experiments
}

\author{
Jaeseok Kim ${ }^{\mathrm{a}}$, Helmi Keskinen ${ }^{\mathrm{a}}$, Petri Vaattovaara ${ }^{\mathrm{a}}$, Pasi Miettinen ${ }^{\mathrm{a}}$, \\ Jorma Joutsensaari ${ }^{\mathrm{a}}$, Annele Virtanen ${ }^{\mathrm{a}}$, and CLOUD collaboration \\ ${ }^{a}$ Department of Applied physics, University of Eastern Finland, Kuopio campus, P.O. Box 1627, FIN- \\ 70211 Kuopio, Finland
}

\begin{abstract}
We investigated hygroscopicity of nucleated nanoparticles derived from dimethylamine and $\alpha$-pinene with sulfuric acid during CLOUD 7 (Cosmic Leaving OUtdoor Droplets) campaign at CERN. The hygroscopicity of nucleated nanoparticles from 10 to $20 \mathrm{~nm}$ in mobility diameter was measured with a nano tandem differential mobility analyzer (nanoTDMA). Here, we present preliminary results from the CLOUD 7 experiments.
\end{abstract}

Keywords: CLOUD, CERN, Nanoparticles, Hygroscopicity, nano-TDMA

PACS: $92.60 . \mathrm{Mt}$

\section{INTRODUCTION}

Nanoparticles in the ambient atmosphere are emitted from natural and anthropogenic sources (i.e., primary aerosols) and generated by homogenous reactions among various vapors (i.e., secondary aerosols). It is necessary to determine their physicochemical properties in order to understand the effect of aerosols on Earth's climate change. ${ }^{1}$ In the current study, we focus on hygroscopicity of nucleated nanoparticles produced by dimethylamine and $\alpha$-pinene with sulfuric acid during CLOUD 7 experiments at CERN. ${ }^{2}$ Results from this study can give indirect sizeresolved chemical composition information of nucleated nanoparticles. ${ }^{3}$

\section{METHODS}

\section{Nano-TDMA System}

The nano tandem differential mobility analyzer (nano-TDMA) was used to measure hygroscopicity of nanoparticles generated inside the CLOUD chamber. The nanoTDMA $^{4}$ consisted of two nano-DMAs ${ }^{5}$ (differential mobility analyzer; TSI 3085), a CPC (condensation particle counter; TSI 3785), and humidifiers as shown in Figure 1. The nucleated nanoparticles were dried and then charged by a bipolar diffusion charger $\left({ }^{85} \mathrm{Kr}\right.$, TSI) before entering first DMA. In the first DMA, particles with certain size $(10,15$, and $20 \mathrm{~nm})$ were selected from the charged polydisperse nanoparticles. The selected nanoparticles passed through an aerosol humidifier consisting of 
GoreTex tubing. After humidifying, size distribution of nanoparticles was measured with second DMA and CPC.

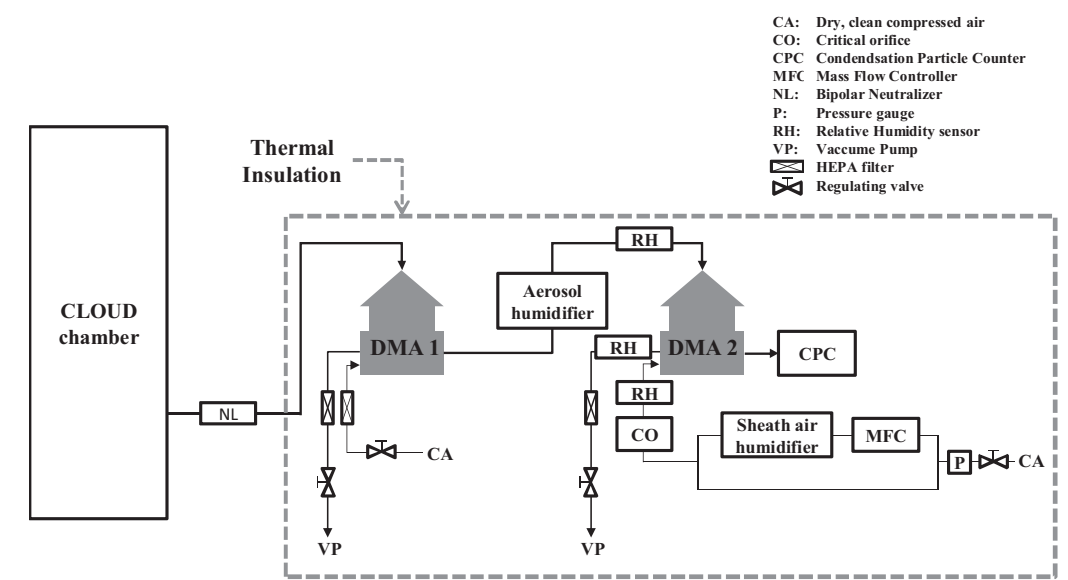

FIGURE 1. A schematic diagram of the nano tandem differential mobility analyzer (nano-TDMA) for measuring hygroscopicity of nucleated nanoparticles.

Before and after CLOUD 7 experiments, we measured hygroscopic growth factor (HGF) and deliquescence relative humidity $(\mathrm{DRH})$ using sodium chloride $(\mathrm{NaCl})$ and ammonium sulfate $\left(\left(\mathrm{NH}_{4}\right)_{2} \mathrm{SO}_{4}\right)$ particles of 10 and $20 \mathrm{~nm}$ to calibrate our nanoTDMA system.

\section{Hygroscopicity of Nucleated Nanoparticles}

Here the hygroscopicity of nucleated nanoparticles was represented by hygroscopic growth factor (HGF) and kappa (k) value. The HGF was defined as the ratio of geometric mean diameter at humidified condition to that at dry condition. In this study, relative humidity (RH) at humidified and dry condition was around $90 \%$ and less than 5\% RH, respectively.

$$
H G F=\frac{d_{G M D}(\text { humidified })}{d_{G M D}(d r y)}
$$

Also, $\mathrm{k}$ value could be calculated based on Eq. $2^{6}$;

$$
\kappa=\left(H G F^{3}-1\right) \cdot\left[\frac{1}{S} \cdot \exp \left(\frac{4 \sigma_{w} M_{w}}{R T \rho_{w} d_{d r y} H G F}\right)-1\right]
$$

where $S$ is the saturation ratio, $\sigma_{w}$ is the water surface tension at room temperature, $M_{w}$ is the molecular weight of water, $R$ is the ideal gas constant, $T$ is the room temperature, $\rho_{w}$ is the density of liquid water. 


\section{PRELIMINARY RESULTS}

We present preliminary results from this study. We observed several size and composition dependent features in hygroscopic behavior of the particles. As particle size increased from $10 \mathrm{~nm}$ to $20 \mathrm{~nm}$, hygroscopicity decreased regardless of experimental condition. It indicates that chemical composition of nanoparticles was changing with size. ${ }^{3}$ According to our observation, nanoparticles generated by dimethylamine- $\mathrm{H}_{2} \mathrm{SO}_{4}$ were more hygroscopic than those produced by $\alpha$-pinenedimethylamine- $\mathrm{H}_{2} \mathrm{SO}_{4}$. This is expected as the hygroscopicity of $\alpha$-pinene is smaller than that of dimethylamine and sulfuric acid. ${ }^{7,8,9}$ Also, in the presence of $\alpha$-pinene in the chamber, the hygroscopicity decreased with increasing size indicating increasing fraction of organics in the particles.

\section{ACKNOWLEDGMENTS}

We would like to thank CERN for supporting CLOUD with important technical and financial resources, and for providing a particle beam from the CERN Proton Synchrotron. This research has received funding from the EC Seventh Framework Programme (Marie Curie Initial Training Network "CLOUD-ITN" no. 215072, MCITN "CLOUD-TRAIN" no. 316662, and ERC-Advanced "ATMNUCLE" grant no. 227463), the German Federal Ministry of Education and Research (project nos. 01LK0902A and 01LK1222A), the Swiss National Science Foundation (project nos. 200020_135307 and 206620_130527), the Academy of Finland (Center of Excellence project no. 1118615), the Academy of Finland (135054, 133872, 251427, 139656, 139995, 137749, 141217, 141451), the Finnish Funding Agency for Technology and Innovation, the Nessling Foundation, the Austrian Science Fund (FWF; project no. P19546 and L593), the Portuguese Foundation for Science and Technology (project no. CERN/FP/116387/2010), the Swedish Research Council, Vetenskapsrådet (grant 2011-5120), the Presidium of the Russian Academy of Sciences and Russian Foundation for Basic Research (grants 08-02-91006-CERN and 12-02-91522-CERN), and the U.S. National Science Foundation (grants AGS1 136479 and CHE1012293).

\section{REFERENCES}

1. IPCC 2007, Climate Change 2007: IPCC Fourth Assessment Report; Cambridge University Press: New York, 2007.

2. J. Kirkby, J. Curtius, J. Almeida, E. Dunne, J. Duplissy, S. Ehrhart, A. Franchin, S. Gagne, L. Ickes, A. Kurten, A. Kupc, A. Metzger, F. Riccobono, L. Rondo, S. Schobesberger, G. Tsagkogeorgas, D. Wimmer, A. Amorim, F. Bianchi, M. Breitenlechner, A. David, J. Dommen, A. Downard, M. Ehn, R. C. Flagan, S. Haider, A. Hansel, D. Hauser, W. Jud, H. Junninen, F. Kreissl, A. Kvashin, A. Laaksonen, K. Lehtipalo, J. Lima, E.R. Lovejoy, V. Makhmutov, S. Mathot, J. Mikkila, P. Minginette, S. Mogo, T. Nieminen, A. Onnela, P. Pereira, T. Petaja, R. Schnitzhofer, J.H. Seinfeld, M. Sipila, Y. Stozhkov, F. Stratmann, A. Tome, J. Vanhanen, Y. Viisanen, A. Vrtala, P.E. Wagner, H. Walther, E. Weingartner, H. Wex, P.M. Winkler, K.S. Carslaw, D.R. Worsnop, U. Baltensperger, and M. Kulmala. Nature 476, 429-433 (2011).

3. H. Keskinen, A. Virtanen, J. Joutsensaari, G. Tsagkogeorgas, J. Duplissy, S. Schobesberger, M. Gysel, F. Riccobono, J. G. Slowik, F. Bianchi, T. Yli-Juuti, K. Lehtipalo, L. Rondo, M. Breitenlechner, A. Kupc, J. Almeida, A. Amorim, E. M. Dunne, A. J. Downard, S. Ehrhart, A. 
Franchin, M.K. Kajos, J. Kirkby, A. Kürten, T. Nieminen, V. Makhmutov, S. Mathot, P. Miettinen A. Onnela, T. Petäjä, A. Praplan, F.D. Santos, S. Schallhart, M. Sipilä, Y. Stozhkov, A. Tomé, P. Vaattovaara, D. Wimmer, A. Prevot, J., Dommen, N. M. Donahue, R.C. Flagan, E. Weingartner, Y.Viisanen, I. Riipinen, A. Hanse, J. Curtius, M. Kulmala, D. R. Worsnop, U. Baltensperger, H. Wex, F. Stratmann and A. Laaksonen, Atmos. Chem. Phys. Discuss. 12, 31071-31105 (2012).

4. H. Keskinen, S. Romakkaniemi, A. Jaatinen, P. Miettinen, E. Saukko, J. Joutsensaari, J. M. Mäkelä, A. Virtanen, J. N. Smith, A. Laaksonen. Aerosol Sci. Tech. 45, 1441-1447 (2011).

5. D.-R. Chen, D. Y. H. Pui, D. Hummes, H. Fissan, F. R. Quant, and G. J. Sem. J. Aerosol Sci. 29(5). 497-509 (1998).

6. M. D. Petters and S. M. Kreidenweis, Atomos. Chem. Phys 7, 1961-1971 (2007).

7. R. C. Sullivan, M. D. Petters, P. J. DeMott, S. M. Kreidenweis, H. Wex, D. Niedermeier, S. Hartmann, T. Clauss, F. Stratmann, P. Reitz, J. Schneider, and B. Sierau, Atmos. Chem. Phys. 10, 11471-11487 (2010).

8. C. Qiu and R. Zhang, Environ. Sci. Tech. 46, 4474-4480 (2012).

9. T. Trischer, J. Dommen, P. F. DeCarlo, M. Gysel, P. B. Barmet, A. P. Praplan, E. Weingartner, A. S. H. Prévôt, I. Riipinen, N. M. Donaue, and U. Baltensperger, Atmos. Chem. Phys. 11, 1147711496 (2011). 